\title{
ESTABLISHING A MODEL TO EVALUATE PUBLIC ADMINISTRATION PROJECTS
}

\author{
Ivan Marović \\ University in Rijeka, Faculty of Civil Engineering, Ph.D. \\ Diana Car-Pušić \\ University in Rijeka, Faculty of Civil Engineering, Ph.D., Associate Professor \\ Zlatko Hrvatin \\ Poduzetnik d.o.o., C.E.
}

\begin{abstract}
Public investment projects are projects in which the public interest is paramount. The public administration generates public projects, which can be grouped into portfolios. We often witness poor, disordered public investment and project selection. One reason is the lack of adequate, consistent methodology for evaluating and selecting projects. It can be difficult to choose from comparable projects within the portfolio, and the attitudes of the stakeholders can hinder decision-making, highlighting the need for multi-criteria analysis. To select the best project, we designed a model to evaluate and rank public administration projects. We presented a hierarchical structure of objectives and criteria for comparing projects. To select and compare projects according to these defined criteria and assigned weights, we used PROMETHEE II. We simulated and validated this model using the portfolio of the city of Kastav. This model contributes to higher quality and more consistent decision-making in selecting the best investment project from a public administration portfolio.
\end{abstract}

Key words: investment project, multi-criteria analysis, decision-making, public administration

\section{USPOSTAVA MODELA VREDNOVANJA PROJEKATA U JAVNOJ UPRAVI}

Sažetak: Javni investicijski projekti su projekti kod kojih bi javni interes trebao biti na prvom mjestu. Pritom javne uprave predstavljaju generatore javnih projekata koji se mogu grupirati u portfelje. Često svjedočimo lošem odabiru i redoslijedu odabira javnih investicijskih projekata. Jedan od razloga leži u nedostatku adekvatne i konzistentne metodologije za vrednovanje i odabir projekata. Prilikom izbora investicijskog projekta iz portfelja javlja se problem izbora najboljeg projekta za investiranje. Problem se očituje u različitim i često teško usporedivim projektima unutar portfelja, ali i stavovima različith zainteresiranih strana. Navedeno upućuje na višekriterijalnost problema i potrebu za primjenom metoda višekriterijalne analize. $U$ radu je za potrebe odabira najboljeg projekta osmišljen model za vrednovanje i rangiranje projekata u javnoj upravi. Predstavljena je hijerarhijska struktura ciljeva, kriteriji za usporedbu projekata, te prema definiranim kriterijima i dodijeljenim težinama je korištena metoda PROMETHEE II. Simulacija i validacija modela provedena je na portfelju grada Kastva kako bi se prikazala provedivost i uporabljivost modela na realnom primjeru. Predstavljenim modelom doprinosi se kvalitetnijem i konzistentnijem donošenju odluka o izboru najboljeg investicijskog projekta iz portfelja javne uprave.

Ključne riječi: investicijski projekt, višekriterijalna analiza, donošenje odluka, javna uprava 


\section{Introduction}

Investment and execution of public projects, through which public services are delivered, is a complex business process that requires special attention, seriousness, and social responsibility, not only from direct public management, but also from the wider social community. Because modern societies move at an accelerating pace and are globally connected, every wrong decision can cause disaster. Policymakers must make quick, accurate decisions with scarce resources, and do not have time to experiment by trial and error. Because of these demands, leaders in public policy need high quality, comprehensive, timely information [1].

The role of public management is to plan and define public policies (strategies), including public investments politics, while the role of the social community is to give public opinions about the proposed policies. Established projects may be grouped into projects databases or portfolios, allowing them to be systematic analyzed and compared.

We often witness poor, disordered choices in public investment projects. These poor choices can be driven by a lack an adequate, consistent methodology to evaluate, select, and implement projects. Selecting among investment projects in a public administration portfolio can often be challenging because the projects are difficult to compare, and because the various interested parties view the projects in different ways. The complexity and multidisciplinarity of this problem suggests the need for multiple-criteria analysis.

To rank the public administrative projects, we devised a model based on multiple-criteria analysis. This model accounts for both the project details and the opinions of various interest groups (the city council, construction and economic experts, and the local population), which has established a hierarchical structure of goals and criteria for mutual comparison of the projects. This paper shows how multiple-criteria analysis can help policymakers choose better, more consistent investments in projects from a public administration portfolio.

\section{Managing Projects in Public Administration}

Different public administrations must work with different environmental requirements. Internal factors influencing the public administration depend on its size, goals, strategies and accessible technologies. External factors include the social, political, and cultural environment, as well as legislation, which can change the way the public administration works [2].

Systems of public administration can be divided into territorial, functional, and associative [2]. The territorial system comprises the administration in a certain area and it proceeds with different dynamics and in different forms. The functional administrative system includes associations and civil organizations, which individuals join to further their interests. The associative system is defined by the relationship between the individual and collective, where the individual follows a certain personal priority or interest that contributes to the organization; in contrast, the territory only provides the framework.

Public administration is dedicated to non-profit activities and social contribution is its most important characteristic. It exists to contribute to the general welfare of the society without financial gain. Investing in a project and choosing its management is challenging for any investor [3], as realizing an investment requires many interconnected, multidisciplinary activities done over time. As mentioned before, public administration is a political body meant to satisfy the public interest; it is able to identify the one common or compromise interest of the entire community within the pluralism of individual interest of particular groups $[4,5]$.

Often, different public administrations use different ways to decide on investments, because determining the common interest from many individual interests can be inconsistent. This problem also occurs in deciding on capital investments in a public administration. This problem can be solved by using systematic decision-making and by establishing a hierarchical goal structure. Multiple-criteria methods are useful, as are other procedures such as a "cup of goals" [6]. 


\section{Establishment of the Project Evaluation Model in Public Administration}

\subsection{Multiple-Criteria Decision-Making}

Multiple-criteria decision-making (MCDM) refers to decision-making that accounts for many criteria, often distinct and conflicting. MCDM can be applied to choosing an investment project from a public administration portfolio. While MCDM is useful in many areas, it should be applied to problems with the following characteristics [5]:

- $\quad$ many criteria - the most important job for the decision-maker is selecting the relevant criteria

- conflicting criteria - the presence of many criteria mean they will most often conflict with each other

- $\quad$ incomparable measurement units - every criterion often has its own unit of measurement, either qualitative and quantitative.

Most challenging decisions are multicriterial, necessitating multiple-criteria decision-making. When deciding using multiple criteria, the decision-maker cannot be replaced, no matter how good the method, and no single method can determine the best solution. At best, it will help the decision-maker strengthen the basis for the decision [5]. When using a multicriterial approach to select an investment project from the public administration portfolio, one must evaluate a great number of criteria, conflicts between criteria, incomparable measurement units of criteria, different weights of criteria, and the choice or ranking of alternative solutions. Reviewing the literature, we found three dominant groups of multiple-criteria analyses:

- $\quad$ ELECTRE [7] methods by Roy (1976)

- $\quad$ AHP [8] methods by Saaty (1980)

- $\quad$ PROMETHEE [9] methods by Brans and Vincke (1984).

When software is used to support a multicriterial decision, PROMETHEE (Preference Ranking Organization Method for Enrichment Evaluation) [5, 9, 10, 11, 12] should generally be used because it was developed [9, 10, 11] to help a decision-maker solve multicriterial tasks. This method is used for comparing and ranking various alternatives (actions) that are simultaneously evaluated based on many quantitative and/or qualitative criteria (attributes). It belongs to a class of outranking methods that comprises the poor dominance relation and assumes the decisionmaker is familiar with the utility functions. In the present paper we used PROMETHEE II, which offers complete ranking of alternatives. We used Visual PROMETHEE software, which has modern architecture and is based on the concept of systematic support in decision-making. This software supports many decision-making processes and can visualize most information and obtained solutions.

\subsection{Project Evaluation Model in Public Administration}

To select the best project, we devised a model for evaluating and ranking projects in public administration (Fig. 1). The model has two stages (two groups of processes): preparatory processes and implementation processes. We followed these stages, first by collecting various projects into a public administration portfolio (i.e., creating a database) and analyzing them, then by comparing the projects with established criteria by using multiple-criteria analysis.

We prepared and implemented the proposed model according to the steps outlined by Gunjača et al. [3]. After determining the project idea, designing the concept, and studying the investment feasibility, one must present the project to potential investors, who must be assured that the future of the project is certain. To do so, it is extremely important to include public administration projects in a database [3]. The information given in the database allows potential investors to consider all aspects of the proposed project. Entering the project into a database is also a precondition for nominating that project for funding, especially important for projects that could be supported by the European Union [3]. After the projects have been entered into the database, they must be analyzed, encompassing the preparatory processes of this model.

Implementing the model begins by defining the goals, establishing the criteria to compare the projects, and by weighting the importance of the criteria. This process creates a goal hierarchy, allowing the projects to be consistently compared with respect to the main goal, i.e., the development strategy. 


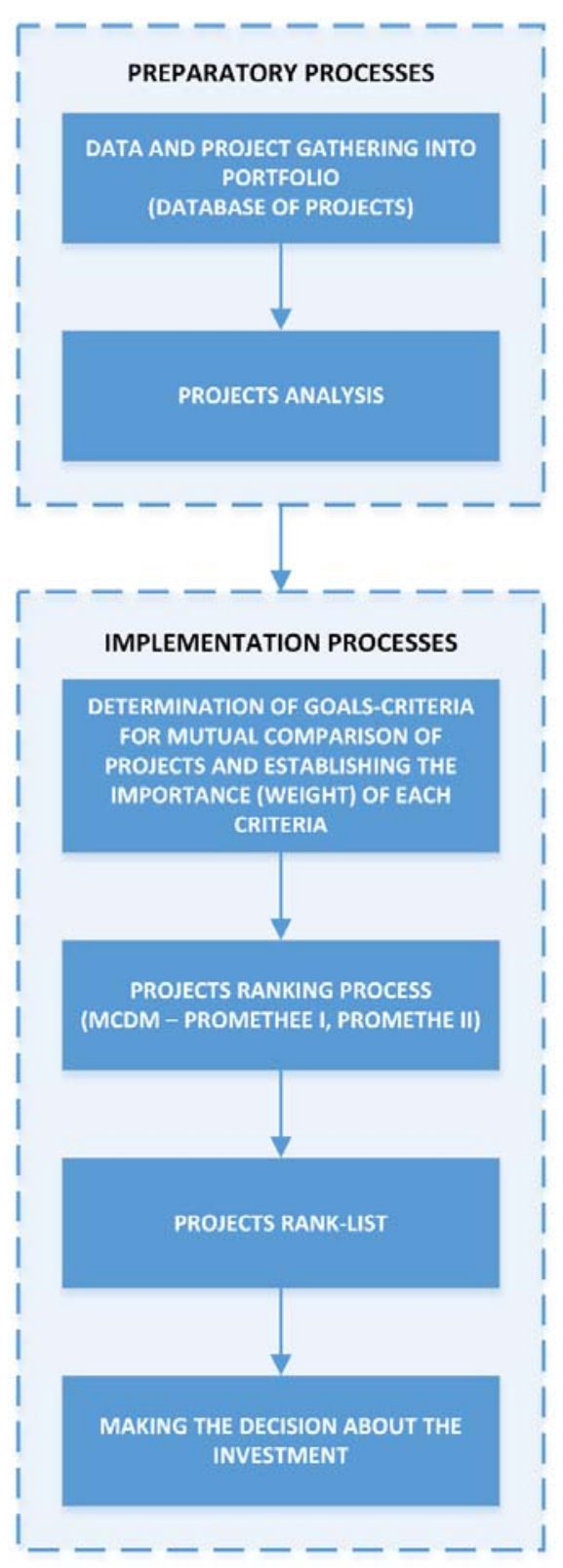

Figure 1. Model for evaluating and ranking projects in public administration

When defining criteria, it is helpful to use "goal analysis" to define the goals that should be achieved by solving the defined problem $[6,13]$. Setting goals is often tedious for decision-makers because decision-makers may be convinced that their goals are clear-even if they are not-and are frequently under pressure to make predetermined decisions. Generally, there is no means of structured goal analysis that is swift, efficient, and systematic; experience and team work are the best guarantee of success in goal analysis [5].

In practice, strategic-level goals frequently conflict. Often, goals coming from external sources conflict with goals from internal sources, often causing the criteria themselves to conflict. This conflict between criteria is exacerbated by poor structuring of problems, and the conflict between dominant criteria is the basic characteristic of "normal" (everyday) problems. This conflict between criteria justifies multiple-criteria analysis, because an optimal solution cannot be determined by using classical methods, including intuitive decision-making [6]. 
Criteria also represent the measure of those characteristics of the system intended to be optimized to satisfy the set goals. When using multiple-criteria analysis, the criteria are usually sorted into the following classes [5]:

- Social-political criteria

- Ecological or safety criteria

- Economic criteria

- Technical and technological criteria.

Establishing a hierarchical goal structure begins by defining the main goal (GC), and then follows the forming of the group, that is the forming of the resource pool of experts (Fig. 2). A selection of first-rank experts (E1R) generates the first-rank goals (C1R). Then, a selection of second-rank experts (E2R) generates the second-rank goals (C2R). This method both generates the goals and establishes a goal hierarchy. Experts of any rank may be individuals, but they can also be groups of experts who may be tasked to determine one group of goals [5] or all goals in one rank.

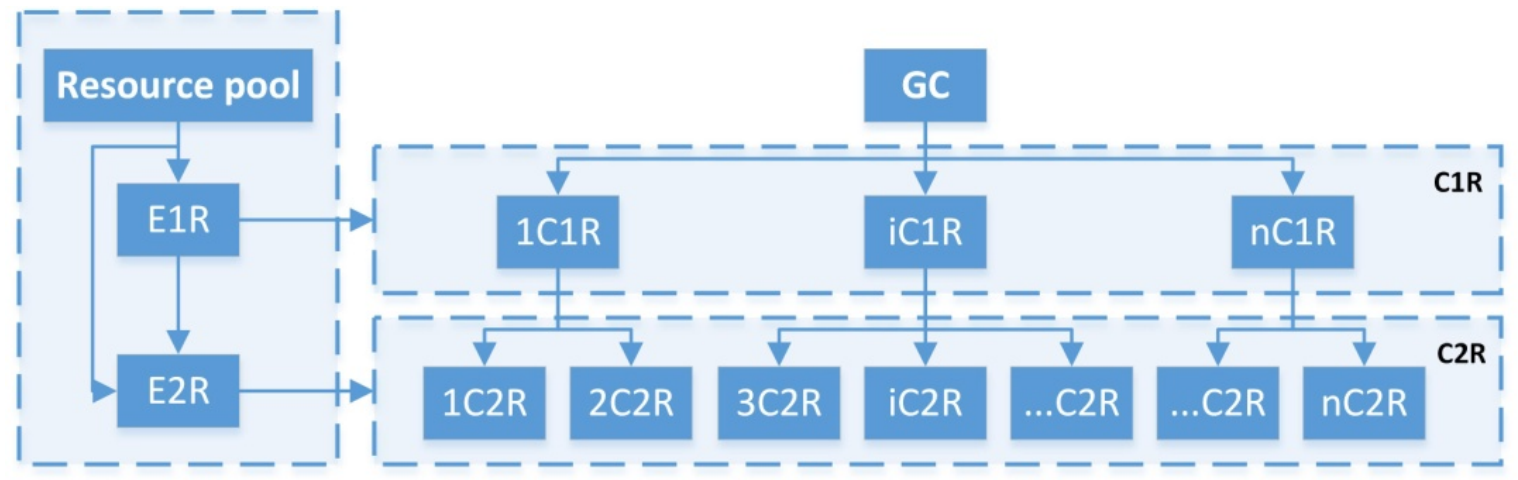

Figure 2. Hierarchical goal structure $[1,5]$

Breaking down the main goal leads to sub-goals and criteria. When a goal can be precisely described and quantitatively measurable, it becomes a criterion. After all goals (C1R and C2R) have been defined, it is necessary to determine their importance. Not all criteria are equally important, so they must be weighted. Weighting is performed by experts who chose the rank of the corresponding goal. The experts should be allowed to choose the weighting scale. After the criteria have been weighted, the assigned amounts must be normalized [5]. In the present paper [14], we established goals (GC - main goal; G1 to G4 - sub-goals, i.e. first-rank goals) and criteria (C1 to C15 - secondrank goals), as shown in Table 1.

Table 1. Review of the terms and symbols of the hierarchical structure of goals

\begin{tabular}{|c|c|l|}
\hline $\begin{array}{c}\text { Hierarchy } \\
\text { level }\end{array}$ & Symbol & \multicolumn{1}{|c|}{ Main goal, sub-goals, and defined criteria } \\
\hline 0 & GC & $\begin{array}{l}\text { Best compromise solution for selecting a public administration } \\
\text { project }\end{array}$ \\
\hline 1 & G1 & Social benefit \\
\hline 1 & G2 & Minimal threat for the environment \\
\hline 1 & G3 & Economic justification \\
\hline 1 & G4 & Technical and town-planning usefulness \\
\hline 2 & C1 & Preservation of cultural heritage and grounds \\
\hline
\end{tabular}




\begin{tabular}{|l|l|l|}
\hline 2 & C2 & Development of sport and recreation \\
\hline 2 & C3 & Development of tourism and tourist offerings \\
\hline 2 & C4 & Share of business premises and catering establishments \\
\hline 2 & C5 & Ecological awareness \\
\hline 2 & C6 & Noise increase \\
\hline 2 & C7 & Pollution of environment \\
\hline 2 & C8 & Local rate and contribution \\
\hline 2 & C9 & Public-private partnership \\
\hline 2 & C10 & Co-financing from European Union funds \\
\hline 2 & C11 & Feasibility \\
\hline 2 & C12 & Integration into existing regional plans \\
\hline 2 & C13 & Number of new parking spaces \\
\hline 2 & C14 & Duration of the project \\
\hline 2 & C15 & Time required to obtain permits \\
\hline
\end{tabular}

After defining the goals, setting the criteria, and weighting them, the projects can be ranked. To rank projects in the present paper, we used PROMETHEE II. This method outputs information as a rank-list of reviewed projects, providing the decision-maker with the basis to make a decision and implement the project.

\section{Implementing Established Model on the Project Portfolio of Kastav}

\subsection{Analyzed Project Portfolio}

The analyzed example is the investment portfolio of the city of Kastav, Croatia. We tested the model on three projects assigned by the city government:

- $\quad$ Project 1 - Reconstruction and conversion of Crekvina

- Project 2 - Kastav Culture Club and Library

- Project 3 - Kastav Centre for Aquatic Sports.

Based on concept designs and numerous discussions with Kastav city-council members, in this paper [14] we performed a detailed analysis of these projects upon which parameters were established for the implementation of the model.

Project 1 - Reconstruction and conversion of Crekvina. This project renovates the historic core of Kastav. The construction zone is the wider surrounding area of the baroque Jesuit Church of St. Mary from the $18^{\text {th }}$ century and a square with a total area of $1224 \mathrm{~m}^{2}$. The newly designed town square has two roles: during the summer as a stage for the Kastav Cultural Summer festival, and during the rest of the year as a free, open space. The impressive existing remains of the church of St. Mary form a spatial "shell"; this ideal scenery of architectural remains would be supplemented with new elements in the space thus creating unique setting for a variety of public and cultural manifestations in the City of Kastav.

Project 2 - Kastav Culture Club and Library. This project expands the cultural and educational community center of the Brothers Matešic Culture Club. This project is intended to expand the existing overage object and to 
supplement it with additional contents (from the outside green area and garage, over numerous new premises to a large hall and the library). In its form, the complex consists of 6 volumes which in their mutual relations follow the morphology of the town and in this way they most neutrally fit into the town's location. Each of the volumes is "inhabited" by contents of a certain type so that every group of contents has its own object with a separate entrance thus giving individual volumes their autonomy in relation to the work regime of the remaining parts of the complex.

Project 3 - Kastav Centre for Aquatic Sports. This project constructs a supplement adjacent to the Kastav Sports Hall and outdoor playgrounds. Situated based on Kastav's regional plans and strategies, it will have three storeys and a "green" roof. It will contain an Olympic swimming pool with 200 audience seats, a smaller swimming pool, and accompanying facilities. This Centre would greatly contribute to the development of sports, and its construction would complete the overall strategy of Kastav regarding the promotion of sports and active participation in sports activities.

\subsection{Selecting the Best Project Using PROMETHEE II}

By analyzing the projects, we established parameters so we could partially compare the projects using each individual criterion. Table 2 shows all the parameters in a decision matrix. It also presents the internal limitations of the method, particularly the measurement units and the scoring method according to the given criteria. It also defines the direction of preference (minimum or maximum) and shows the preference function.

As previously discussed, we ranking the projects from the public administration portfolio by using PROMETHEE II, specifically Visual PROMETHEE software. This method requires, in addition to inputting the basic parameters and weighting the criteria in the decision matrix, choosing the type of criterion through which possible incoherence in the data set and preference functions can be corrected. It is necessary to form a complex preference relation to emphasize that this outranking relation is based on many criteria and that it is founded on generalizing those criteria.

Defining the preference indices generates a complex preference relation, shown by using a preference graph. The essence of this step is in the fact that the decision-maker must give priority to one of the two alternatives, i.e. actions (activities) in each of the criteria, based on the difference between the criteria values of the compared alternatives.

For criteria C1, C2, C3, C4, C5, C9, C10, C12, and C13, we chose the Usual Preference Function because, for the decision-maker, all activities are indifferent as long as the differences between their values do not exceed the threshold of indifference. When these differences do exceeds this threshold, we can define a strict preference. For the remaining criteria $(\mathrm{C} 6, \mathrm{C} 7, \mathrm{C} 8, \mathrm{C} 11, \mathrm{C} 14$, and $\mathrm{C} 15)$, the decision-makers did not clearly see the possible areas of indifference between the possible activities; in other words, they considered the differences in the values of the solutions expressed through these criteria as very important. Thus, for these criteria we used the V-shape Preference Function, which well describes the attitudes of these decision-makers.

In addition to collating the input data (Table 2), it is also necessary to weight the importance of the defined criteria. To do so, we used the procedure shown in Fig. 2. To determine the hierarchical goal structure and the relative importance of those goals (Table 3), we used three expert groups:

- Expert 1 - Construction and economic experts

- Expert 2-Local population

- $\quad$ Expert 3-City government.

Based on the defined strategy, which represents the main goal - GC, we also defined sub-goals (G1-G4) and criteria (C1-C15), as explained in Section 3.2. Experts from each expert group assigned weights to every goal and criterion, as shown in Table 3. All sub-goals and criteria derive from the main goal: criteria C1-C4 derive from subgoal $\mathrm{G} 1$, criteria $\mathrm{C} 5-\mathrm{C} 7$ derive from sub-goal $\mathrm{G} 2$, criteria $\mathrm{C} 8-\mathrm{C} 10$ derive from sub-goal $\mathrm{G} 3$, and criteria $\mathrm{C} 11-\mathrm{C} 15$ derive from sub-goal G4.

The compromise between expert groups was determined as the arithmetic mean of the weightings those groups chose. PROMETHEE II assessed four solutions or scenarios with the same decision matrix (Table 2) with the assigned weights from every expert group (Table 3). Scenarios 1, 2, and 3 are the solutions based on the preference of only one expert group, whereas scenario 4 is the solution based on their compromise.

Marović, I; Car-Pušić, D; Hrvatin, Z 
e-GFOS 5, 8 (2014)

Table 2. Input parameters - decision matrix

\begin{tabular}{|c|c|c|c|c|c|c|c|c|c|}
\hline \multirow{17}{*}{ 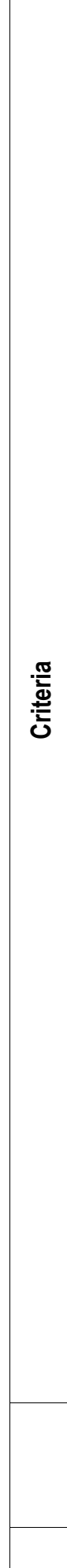 } & \multirow{5}{*}{ 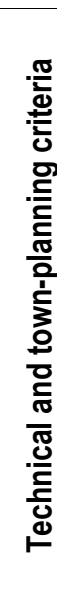 } & $\frac{n}{0}$ & $\sim$ & $\sim$ & $m$ & $\cdot \stackrel{\complement}{E}$ & $\stackrel{p}{\varphi}$ & 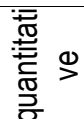 & 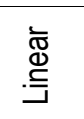 \\
\hline & & ¿ & $\sim$ & $m$ & m & $\cdot$ ·高 & $\stackrel{1}{1}$ & 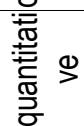 & 㐫 \\
\hline & & $\frac{m}{\delta}$ & $r$ & $m$ & $\sim$ & 希 & $\stackrel{1}{1}$ & 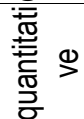 & 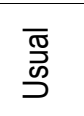 \\
\hline & & บั & $\stackrel{\mathscr{D}}{\stackrel{2}{2}}$ & 음 & 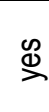 & 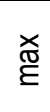 & $\stackrel{ᄃ}{\curvearrowright}$ & 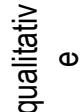 & $\begin{array}{l}\overline{\widetilde{T}} \\
\stackrel{D}{S}\end{array}$ \\
\hline & & $\overline{\mathrm{c}}$ & $\infty$ & r & $\sigma$ & $\stackrel{\text { đ }}{E}$ & 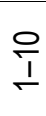 & 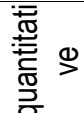 & 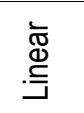 \\
\hline & $\frac{-\pi}{\frac{\pi}{d}}$ & 은 & $\stackrel{\mathscr{\Phi}}{\stackrel{1}{2}}$ & $\stackrel{\mathscr{D}}{\stackrel{1}{2}}$ & $\stackrel{\mathscr{\infty}}{\stackrel{2}{2}}$ & $\cdot \stackrel{\subseteq}{E}$ & $\stackrel{c}{\lambda}$ & 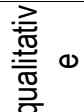 & $\begin{array}{l}\overline{\widetilde{T}} \\
\stackrel{\vec{D}}{د}\end{array}$ \\
\hline & o & S & ㅇ & ㅇ & $\stackrel{\mathscr{\infty}}{\stackrel{1}{2}}$ & · & $\frac{5}{\lambda}$ & 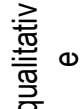 & 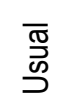 \\
\hline & نَ & ఝ & $>$ & - & ᄃ & 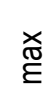 & $\stackrel{p}{\varphi}$ & 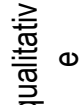 & $\stackrel{\stackrel{\bar{\varpi}}{\mathscr{\Xi}}}{\stackrel{\Xi}{\Xi}}$ \\
\hline & - & $\hat{U}$ & - & - & $\sim$ & $\cdot \stackrel{\bar{E}}{\mathrm{E}}$ & $\stackrel{p}{?}$ & 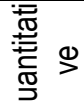 & $\begin{array}{l}\stackrel{\bar{\varpi}}{\Phi} \\
\stackrel{\Xi}{=}\end{array}$ \\
\hline & $\frac{\bar{t}}{\frac{0}{0}}$ & 8 & $\sim$ & - & $m$ & $\cdot \frac{\subseteq}{\mathrm{E}}$ & $\stackrel{p}{\sim}$ & 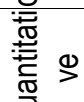 & 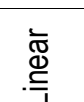 \\
\hline & 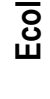 & S & $\nabla$ & ما & $m$ & $\stackrel{\text { ख }}{E}$ & $\stackrel{p}{1}$ & 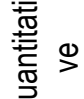 & $\begin{array}{l}\overline{\widetilde{O}} \\
\stackrel{\mathrm{p}}{\rho}\end{array}$ \\
\hline & & తే & مـ & $\sigma$ & or & 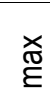 & $\stackrel{p}{1}$ & 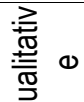 & $\begin{array}{l}\overline{\widetilde{D O}} \\
\overline{\mathrm{D}}\end{array}$ \\
\hline & $\begin{array}{l}\frac{\pi}{0} \\
\frac{\pi}{20} \\
\frac{\pi}{0}\end{array}$ & $\tilde{\mathcal{O}}$ & $m$ & - & $\checkmark$ & $\stackrel{\text { बै }}{E}$ & $\stackrel{p}{1}$ & 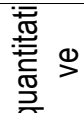 & $\begin{array}{l}\overline{\widetilde{J}} \\
\stackrel{\widetilde{D}}{\rho}\end{array}$ \\
\hline & $\begin{array}{l}\frac{\bar{\pi}}{4} \\
\text { क }\end{array}$ & ชิ & - & - & م & 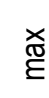 & $\stackrel{p}{\sim}$ & 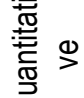 & $\begin{array}{l}\overline{\widetilde{T}} \\
\stackrel{\vec{D}}{\mathcal{S}}\end{array}$ \\
\hline & & $\bar{\delta}$ & N & 음 & $\sim$ & 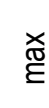 & $\stackrel{ }{\underline{1}}$ & 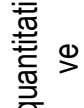 & $\begin{array}{l}\overline{\underline{g}} \\
\stackrel{\widetilde{S}}{\mathcal{S}}\end{array}$ \\
\hline & & & 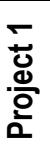 & $\frac{N}{\stackrel{N}{0}}$ & 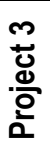 & $\sum_{\sum}^{x}$ & 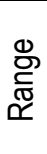 & 䓂 & 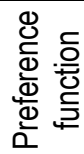 \\
\hline & & & & roje & & & out & itation & \\
\hline
\end{tabular}


e-GFOS 5, 8 (2014)

Table 3. Criteria weightings

\begin{tabular}{|c|l|c|c|c|c|}
\hline Criterion & \multicolumn{1}{|c|}{ Main goal, sub-goals and defined criteria } & Expert 1 & Expert 2 & Expert 3 & AVG \\
\hline GC & $\begin{array}{l}\text { Best compromise solution for selecting a public } \\
\text { administration project }\end{array}$ & 100 & 100 & 100 & 100 \\
\hline G1 & Social benefit & 27 & 35 & 48 & 37 \\
\hline G2 & Minimal threat to environment & 20 & 23 & 16 & 20 \\
\hline G3 & Economic justification & 23 & 21 & 16 & 20 \\
\hline G4 & Technical and town-planning usefulness & 30 & 21 & 20 & 24 \\
\hline C1 & Preservation of cultural heritage & 6 & 10 & 12 & 9,3 \\
\hline C2 & Development of sport and recreation & 7 & 8 & 13 & 9,3 \\
\hline C3 & Development of tourism & 8 & 9 & 14 & 10 \\
\hline C4 & Share of business premises and catering & 6 & 8 & 9 & 7,6 \\
\hline C5 & Establishments & & & & \\
\hline C6 & Noise increase & 4 & 8 & 6 & 6 \\
\hline C7 & Pollution & 3 & 7 & 4 & 4,7 \\
\hline C8 & Local rate and contribution & 13 & 8 & 6 & 9 \\
\hline C9 & Public-private partnership & 9 & 8 & 4 & 7 \\
\hline C10 & Co-financing from EU funds & 4 & 6 & 3 & 4,3 \\
\hline C11 & Feasibility & 10 & 7 & 9 & 8,7 \\
\hline C12 & Integration into existing regional plans & 4 & 7 & 7 \\
\hline C13 & Number of new parking spaces & 4 & 3 & 4 \\
\hline C14 & Project duration & 4 & 4 & 4,3 \\
\hline C15 & Time required to obtain permits & 4 & 3 & 4 \\
\hline
\end{tabular}

\subsection{Results of Implementing PROMETHEE II}

Table 4 shows the results of numerically processing the inputted data. Using PROMETHEE II, we obtained the total Phi values of the flows; the method provided us with the sums of all input and output flows, i.e. with the domination ratios of particular pairs of actions. 


\section{Table 4. Results of PROMETHEE II}

\begin{tabular}{|c|c|c|c|c|c|c|c|c|}
\hline \multirow{2}{*}{ Project } & \multicolumn{2}{|c|}{ Scenario 1 } & \multicolumn{2}{c|}{ Scenario 2 } & \multicolumn{2}{c|}{ Scenario 3 } & \multicolumn{2}{c|}{ Scenario 4 } \\
\cline { 2 - 9 } & RB & Phi & RB & Phi & RB & Phi & RB & Phi \\
\hline Project 1 & 3 & -0.0850 & 3 & -0.1400 & 3 & -0.1750 & 3 & -0.1000 \\
\hline Project 2 & 2 & -0.0350 & 1 & 0.0850 & 2 & -0.0250 & 1 & 0.0600 \\
\hline Project 3 & 1 & 0.1200 & 2 & 0.0550 & 1 & 0.2000 & 2 & 0.0400 \\
\hline
\end{tabular}

Note that one and the same project is not always given the best rank according to all scenarios. Even if one project was the best according to most scenarios, it is not necessarily the best compromise. By analyzing the scenarios, we observed how changing the criterion weight influenced the solution. From these observations we conclude that the established importance (weight) is very important to implementing multiple-criteria analysis, and that including all interested parties allows them to reach a more comprehensive solution. Figure 3 shows the results of implementing PROMETHEE II, graphically comparing the scenarios.

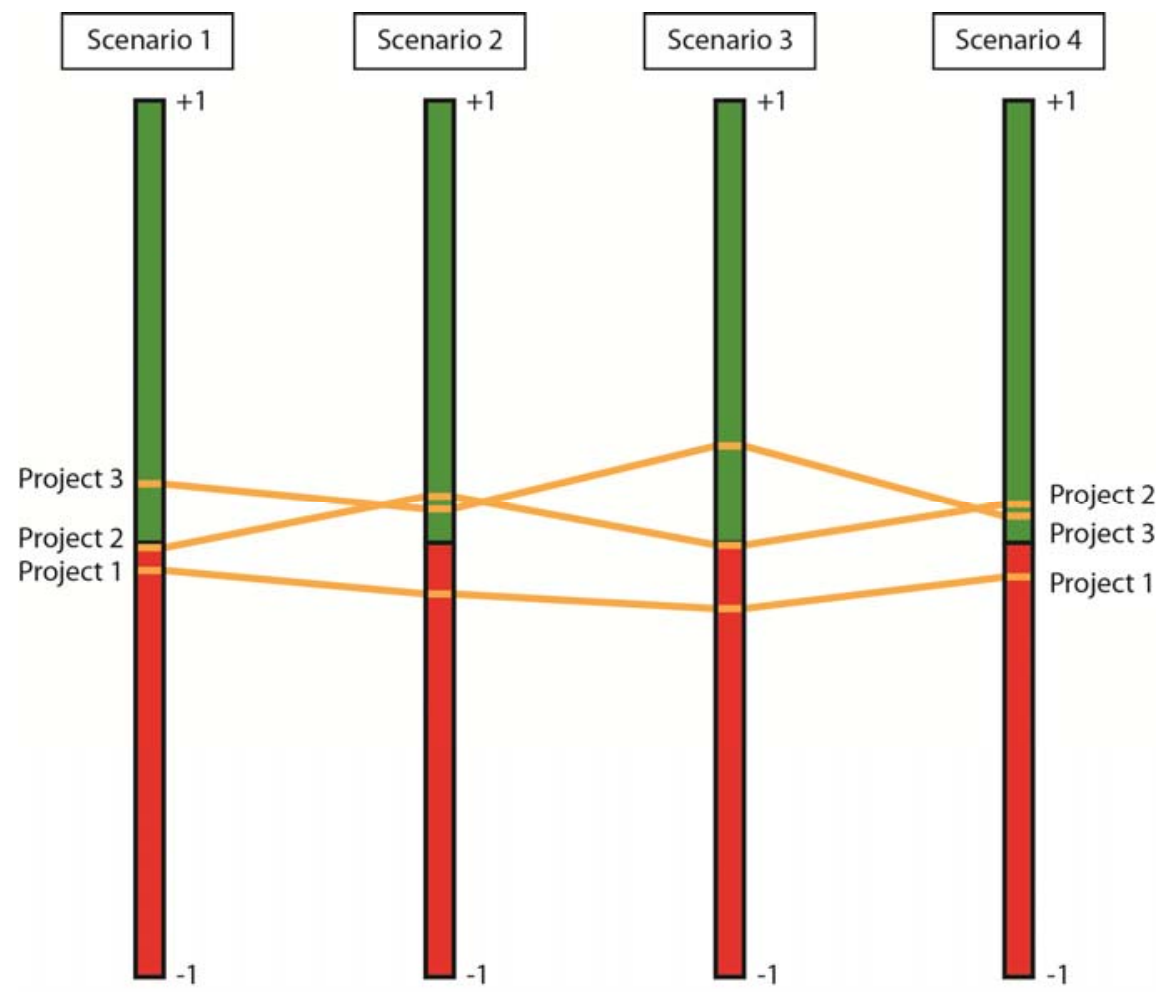

Figure 3. Results of implementing PROMETHEE II, comparing scenarios

Figure 3 shows the differences between the rankings of the individual groups and the total result. Every scenario represents the solution obtained by PROMETHEE II. Among scenarios 1-3, particular projects were better ranked than the others. This result occurred because, apart from the objective elements of comparison (Table 2), subjective influence was also significant. This subjective influence came from the differences in weightings among the expert groups (scenarios 1-3). These results show why decision-making should include the views of many interest groups, allowing for a solution that is a better compromise. 


\section{Conclusion}

We presented a model for evaluating and ranking projects in a public administration based on multiple-criteria analysis. The model was fed with project information and data on the views of interest groups (city government, construction and economic experts, and local population), and the hierarchical structure of the goals and of the criteria for mutual comparison of projects was also introduced. Implementing multiple-criteria analysis led to better quality, more consistent decisions in this demonstration.

This model is valuable because it improves the consistency of decision-making and gives the decision-maker a feeling of safety because he knows that, if he has followed the procedure proposed by the presented model, he did not bring a false decision but a decision that is rational, systematically and carefully considered and based on compromise. The advantage of such approach to decision-making lies in the fact that even if it comes to a change in the structure of decision-makers, the decision-making procedure itself remains consistent.

\section{References}

[1] Marović, I. 2013: Strategic decision making - choosing the investment project out of public administration portfolio, Eds. Divić, V., Trogrlić, B., Gotovac, H., Zajednički temelji, 39-40. University of Split, Faculty of Civil Engineering, Architecture and Geodesy, Split (in Croatian)

[2] Kanoti, D. 2007: Information technology and management culture as a success factor of public administration, M.Sc. Thesis, University of Zagreb, Faculty of Organization and Informatics, Varaždin (in Croatian)

[3] Gunjača, N.; Linić, V.; Medvedec, D.; Pranjić, I.; Urek, R. 2013: Preparation and realization of investments in public procurement, Croatian Association of Accounting and Financial Personnel, Zagreb (in Croatian)

[4] Bošković, D. 2012: Lectures in project management, manuscript, University of Rijeka, Faculty of Civil Engineering, Rijeka (in Croatian)

[5] Marović, I. 2013: Decision support system in real estate value management, Dissertation, University of Zagreb, Faculty of Civil Engineering, Zagreb (in Croatian)

[6] Jajac, N. 2010: Decision support system for development and maintenance of urban road infrastructure, Dissertation, University of Split, Faculty of Economics, Split (in Croatian)

[7] Roy, B. 1976: From optimization to multicriteria decision aid: Three main operational attitudes, Eds. Thieriez, H., Zionts, S., Multiple Criteria Decision Making: Theory and Application, Springer-Verlag, Berlin, pp 1-34

[8] Saaty, T. L. 1980: The Analytic Hierarchy Process, McGraw-Hill, New York

[9] Brans, J.P., Vincke, Ph. 1984: Preference Ranking Organisation Method for Enrichment Evaluations (The PROMETHEE Method for Multiple Criteria Decision Making), Centrum voor Stratistiek en Operationeel Ondezoek, Vrije Universiteit, Brussel

[10] Bran, J.-P.; Mareshal B.; Vincke Ph. 1984: PROMETHEE: A new family of outranking methods in MCDM, Ed. Brans, J.-P., Operational Research '84 - Proceedings of the 10th IFORS International Conference on Operational Research, Elsevier Science Publishers, Washington, pp 477-490

[11] Brans, J.-P.; Mareshal, B. 1994: How to decide with PROMETHEE, Universite Libre de Bruxelles, Bruxelles

[12] Jajac N.; Bilić I.; Mladineo M. 2012: Application of multicriteria methods to planning of investment projects in the field of civil engineering, Croatian Operational Research Review, Volume 3, pp 113-124

[13] Mladineo, N. 2006: Research of the optimization methods for production transport and usage of the ready mixed concrete, Dissertation, University of Split, Faculty of Civil Engineering and Architecture, Split (in Croatian)

[14] Hrvatin, Z. 2013: Establishment of the project evaluation model in public administration, Master Thesis, University of Rijeka, Faculty of Civil Engineering, Rijeka (in Croatian) 